\title{
Aproximação e distanciamento: o interesse de Brecht por Stanislavski
}

\author{
Iná Camargo Costa
}

\section{Introducão}

1 mbora a grande contribuição de Stanislavski para o trabalho do ator tenha ocorrido nos últimos anos do século XIX e início do século XX, somente após a revolução de Outubro de 1917 seu trabalho começou a ser sistematizado. A obra por ele publicada em vida, e única não-sistemática, Minha vida na arte, é de 1923-1925. ${ }^{1}$ Muito depois de sua morte (1938) é que se publica na URSS $O$ trabalho do ator sobre si mesmo (1955), em dois volumes que no Ocidente ficaram conhecidos como $A$ preparação do ator e $A$ criação de um papel, e finalmente em 1957 é publicada $A$ construção da personagem.

Estas três obras sistemáticas, que propriamente constituem o 'método stanislavski', foram publicadas no Brasil entre os anos de 1960 e 1970, sempre em tradução das ediçôes americanas, que começaram a sair nos Estados Unidos em 1936 graças ao empenho de Elizabeth Reynolds Hapgood. ${ }^{2}$ Dessas primeiras informações, já se pode afirmar com Brecht que no Ocidente o sistema Stanislavski surgiu como um tema do teatro americano de esquerda, ${ }^{3}$ que primeiro discutiu "o método" a sério.

Como não é o caso de repisar aqui algumas das informaçóes básicas sobre a trajetória de Stanislavski, já que elas estão disponíveis nas ediçōes brasileiras de suas obras fundamentais, trataremos apenas de suas compreensíveis relações com a Revolução, pois estas respondem pelo modo como Brecht reagiu à sua "canonização" pelos stalinistas.

Para que não se perca o senso das proporções, porém, não custa lembrar que em 1917, Stanislavski já estava com 54 anos e sua própria

Iná Camargo Costa é Professora no Departamento de Teoria Literária e Literatura Comparada da FFLCH-USP.

1 Devo esta e as demais informações sobre edições soviéticas da obra de Stanislavski a Arlete Cavalieri, a quem faço questão de agradecer. A obra completa em russo, Sobranie sochinenii, foi publicada em oito volumes entre os anos de 1954 e 1961 (cf. Rudnitsky, 2000. Como veremos adiante, esta informação é relativa à URSS, pois nos Estados Unidos o caso é diferente.

2 Cf. prefácios e/ou notas editoriais das edições brasileiras, todas da Editora Civilização Brasileira.

3 A edição portuguesa de $A$ compra do latão (Brecht, 1999), a propósito de uma sugestão de exercício stanislavskiano para atores, informa que Brecht está citando um ensaio (provavelmente uma resenha) de Rapaport publicado em 1936 na revista americana Theatre Workshop, número 1, com o título The work of the actor (o mesmo da tradução de Elizabeth Hapgood). Em 1937, a mesma revista publicou um outro estudo em seu número 2, The actor's creative work, de Sudakov. Há várias referências ao ensaio de Rapaport em A compra do latão. 
revolução teatral, de que trataremos adiante, completara 22 anos (o Teatro de Arte de Moscou, doravante a ser referido como TAM, estreou em 1898). Sem se apresentar propriamente como hostil às providências da Revolução no campo das artes cênicas (à diferença de alguns de seus mais famosos discípulos, como Vakhtangov e Meyerhold, que aderiram com entusiasmo), Stanislavski limitou-se inicialmente a defender seu território e sua concepção edificante de teatro (espaço onde os trabalhadores poderiam aprender "bons modos"), no que teve bastante sucesso. Em retribuição, os revolucionários asseguraram a continuidade de seu trabalho, no interesse adicional de preservar bons exemplos da "velha cultura" (cf. Edwards, 1965, p. 92).

Mantendo basicamente a rotina do TAM (encenação preferencial de peças de Tchekhov e Gorki), Stanislavski e seus discípulos não abandonaram de todo a experimentação, quando possível apresentando 'peças novas' que claramente dialogavam com os acontecimentos e, em momentos cruciais, registravam posições e mesmo diagnósticos importantes. Para não entrar em detalhes que nos levariam longe demais, limitemo-nos a referir a primeira experiência nova, o Caim de Byron (texto de 1821), que adota o ponto de vista do fratricida em plena guerra civil (o espetáculo é de 1920). Alguns anos depois, em 1926, Stanislavski patrocinou a encenação da peça de Bulgakov, Os dias dos Turbins (direção de Sudakov), um dos maiores sucessos do TAM em tempos soviéticos (só saiu de cartaz em 1941), que foi violentamente criticada. Um detalhe que não escapou a Brecht: durante a consolidação da corrente stalinista no poder, a peça tem por assunto as tribulações de uma família ligada ao exército contra-revolucionário durante a guerra civil e não esconde a simpatia por essa gente.
Mas diga-se também, e a bem da verdade, que nesse mesmo ano de 1926, o próprio Stanislavski dirigiu a montagem de Coraçôes ardentes (Ostrovski), espetáculo que Meyerhold considerou perfeito e, para Brecht, que o assistiu com enorme prazer em 1955, manifestava "toda a grandeza de Stanislavski" (Brecht, 1973, p. 555). Para o leitor de Minha vida na arte, esta convergência é menos surpreendente do que parece.

Para concluir esse vôo rasteiro, cabe ainda lembrar que, após o ataque cardíaco sofrido durante as comemoraçóes do trigésimo aniversário do TAM (1928), o diretor diminuiu radicalmente as suas atividades, o que não o impediu de acompanhar de longe a encenação do Otelo em 1930 (que finalmente saiu como ele queria), nem de dirigir em 1932 uma adaptação de Almas mortas (Gogol), seu último espetáculo. A essa altura (estamos a dois anos do Congresso de Escritores que proclamará a palavra de ordem do realismo socialista), o Teatro de Arte de Moscou já dá régua e compasso ao teatro soviético hegemônico.

\section{A revolução stanislavskiana}

Em Minha vida na arte (1985), Stanislavski reconstitui de modo vivo e extremamente interessante as diferentes linhas e períodos que marcaram a trajetória do TAM até os anos 1920. De seus relatos é possível abstrair com razoável dose de verdade (como ele gostava) os dois passos que devidamente combinados configuram a revolução levada a efeito por ele e demais companheiros daquela companhia.

Depois de um primeiro período atuando, dentro do possível, nos moldes da tradição ${ }^{4}$ ainda presente nos teatros russos, surge para eles, por iniciativa de Nemiróvitch-Dántchenko o

4 Nas palavras do diretor: "(crítica e público) não percebiam que o detalhismo na caracterização (cenário e figurinos) era um modo de disfarçar a imaturidade do elenco". Ironicamente, ainda comenta que o TAM vivia um claro paradoxo: contando com atores que mal sabiam caminhar no palco, todos tratavam com grande menosprezo o teatro e o ator da velha escola (Stanislavski, 1985, p. 235). 
problema Tchekhov, ${ }^{5}$ que foi mais ou menos resumido nestes termos: "Todos os teatros da Rússia e muitos europeus tentaram encenar Anton Tchekhov utilizando os recursos cênicos tradicionais. Todas as tentativas fracassaram. E deve-se ter em conta que suas peças [...] eram representadas pelos melhores artistas do mundo" (Ibid., p. 245).

Trocando em miúdos, e permanecendo nas formulações de Stanislavski, o problema decorria da insatisfação produzida pelas leituras e encenações das peças do dramaturgo, para não falar em incompreensão mesmo. Assumindo a máscara de leitor desavisado, o diretor enumera as suas próprias decepções com essas peças: são pouco teatrais, monótonas, entediantes, não apresentam nada de particular, nada de surpreendente, nada de novo; não se sabe o que interessa, se a fábula ou o tema; nenhum dos personagens se destaca a ponto de interessar a um grande ator e assim por diante.

Com vasta experiência literária, Nemiróvitch-Dántchenko, o primeiro diretor do TAM, ensinou a Stanislavski e ao elenco da companhia como ler e buscar o caminho para interpretar corretamente a obra do amigo dramaturgo, que até então só tivera decepções. Entre outras coisas, ele reclamava do que hoje chamamos superrepresentação, aquela maneira de atuar que produz uma clara percepção de artificialismo e, quando exagerada às raias da caricatura involuntária, no Brasil desqualifica o praticante como canastrão. ${ }^{6}$ Depois de muita ruminação, conta Stanislavski, "nós nos convencemos de que era impossível separar forma de conteúdo, ou seja, o aspecto literário, psicológico ou social, das imagens e da expressão necessária que, em seu conjunto, concretizavam em cena a arte da poesia [de Tchekhov]” (Ibid., p. 249). A partir dessa compreensão conseguiram "transpor para a cena alguma coisa do que está em Tchekhov" na medida em que encontraram uma nova maneira de encená-lo, uma maneira muito particular, que foi a principal contribuição do TAM para a arte dramática (Ibid., p. 245).

Esta maneira nova e "natural" - por oposição à artificial acima referida -, que depois constituirá o núcleo do "método", em Minha vida na arte deriva da linha de trabalho voltada para a "intuição" e o "sentimento" e foi descoberta na busca de alternativas aos clichês e convencionalismos que ainda imperavam até mesmo nos mínimos detalhes dos trabalhos do próprio TAM. Na encenação de $A$ gaivota (1901) foram dados grandes passos, mas nem tudo se resolveu, como o próprio Tchekhov sugeriu ao criticar o figurino escolhido pelo próprio Stanislavski para seu personagem Trigorin. O dramaturgo observou-lhe na estréia que este devia usar botas surradas e calça xadrez (Stanislavski usara roupas brancas e complementos impecáveis, demorando bastante para entender seu erro "técnico").

Depois de compreendidas, as peças de Tchekhov puderam finalmente apresentar no palco as mesmas delícias encontradas por leitores como Dántchenko. Segundo os achados de Stanislavski, elas têm ação e movimento em doses gigantescas, mas não nas manifestações exteriores e sim em seu desenvolvimento interno. Tchekhov provou que a ação cênica pode se concretizar no sentimento e este pode fundamentar a cena; o ator não tem que representar (segundo as convençôes agora superadas), tem que ser, viver seu personagem. Quem faz os personagens de Tchekhov precisa perceber que

5 A experiência com as peças de Ibsen também é muito reveladora, mas a sua reconstituição nos levaria longe demais.

6 Em carta de 27/09/1889 a Aleksei Suvórin, editor de um jornal de São Petersburgo, Tchekhov comenta sobre a estréia de uma de suas peças: "Os homens não sabem os seus papéis e representam razoavelmente; as damas sabem os papéis e representam mal.” (Cf. Tchekhov, 2002, p. 264) 
com muita freqüência eles dizem precisamente o que não sentem, que há um claro desencontro entre discurso e sentimento e isso precisa vir para a cena sem maior alarde. Mais ainda: este dramaturgo dispensa as vivências triviais que provêm da superfície da alma; suas peças já não precisam das sensaçóes desgastadas, desmoralizadas e convencionais que perderam toda intensidade. Sua especialidade é expor estados de espírito que freqüentemente são intraduzíveis em palavras; pressentimentos, alusões, sinais e sombras de sentimentos que vêm do fundo da alma e, em contato com eles, as almas do ator e do público se inflamam, produzindo sentimentos vivos, mesmo que ainda sem nome. Com um detalhe nada desprezível: estes sentimentos e sensações estão impregnados da poesia sempre fresca e florescente da vida das ruas (Ibid., p. 2469).

Em outras palavras, ao escrever suas memórias, Stanislavski tem plena consciência de que a novidade produzida por seu teatro foi uma linguagem cênica (obra coletiva que envolveu atores, diretor, dramaturgista, cenógrafo e demais 'técnicos') capaz de traduzir o novo conteúdo das peças de Tchekhov: relaçôes, sentimentos, palavras, ritmos (pausas), gestos, etc., correspondentes a uma experiência histórica que não tinha equivalente na dramaturgia nem no repertório teatral herdados por sua geração. É este o feito que ele reivindica.

Mas sua revolução só se completará no passo seguinte, igualmente promovido por Tchekhov e Nemiróvitch-Dántchenko. O primeiro apresenta Gorki ao TAM e convence seus dirigentes de que só eles seriam capazes de traduzir cenicamente a sua obra literária. E o segundo novamente ensina "como ler" Gorki. Stanislavski lembra que a conjuntura pré-revolucionária (ele se refere à revolução de 1905) já levara a escola que mantinham a selecionar para seus cursos de preferência candidatos provenientes das "massas populares": "a efervescência revolucionária e o nascimento da revolução trouxeram para o teatro toda uma série de obras que refletiam os ânimos político-sociais de des- contentamento, protesto e sonhos com um herói capaz de dizer a verdade com energia”, diz ele (p. 278) a propósito de seu próprio sucesso no papel de Dr. Stockmann, em $O$ inimigo do povo, de Ibsen.

Das peças que Gorki estava escrevendo, a primeira que ficou pronta foi Os pequenos burgueses, encenada pelo TAM na temporada 19012. A experiência não deu muito certo, mas parte importante da responsabilidade pela frustração deve ser debitada à eficiente vigilância da censura e da polícia sobre o dramaturgo e, em decorrência da 'perigosa' aproximação, sobre a companhia teatral. Para começo de conversa, a peça só foi liberada depois de demoradas negociações, com cortes, mas apenas para os sócios (os abonados burgueses e aristocratas que ajudavam a manter a companhia através de assinaturas) e não para o público em geral. Além disso, uma série de incidentes, desde o ensaio geral aberto apenas a convidados (cercado por policiais como numa operação de guerra), acabou levando à desistência da empreitada.

Com Ralé, na temporada seguinte, peça na qual Stanislavski fez o papel de Satin, o TAM deu o segundo passo. Em suas palavras: "Novamente estávamos às voltas com um problema difícil; um tom novo e uma nova maneira de representar, uma nova vida, um romantismo insólito, uma ênfase que por um lado beirava à mais perfeita teatralidade e, por outro, ao sermão. Quando se trata das obras de Gorki, é preciso dizê-las de modo tal que cada frase tenha som e vida. Seus monólogos didatizantes e próximos da pregação [...] têm que ser pronunciados com simplicidade, com elevação natural interior, sem falsa teatralidade nem grandiloqüência; do contrário, corre-se o risco de transformar uma obra séria em melodrama vulgar. Foi preciso apropriar-se do estilo peculiar do vagabundo, sem o confundir nem mesclar com o tom teatral comum das peças de costume, e ainda menos com a declamação falsa e vulgar." (Ibid., p. 282) Para realizar tal proeza, todo o elenco do TAM tratou de excursionar pelo submundo dos albergues noturnos, onde acabou encontrando 
a matriz real da "poesia das ruas" que, como Tchekhov em outro registro, Gorki elaborou literariamente e queria ver e ouvir no teatro. Com esta experiência, Stanislavski, pelo menos, aprendeu a utilizar "material vivo" para o seu trabalho de criação de "homens e imagens".

Ralé fez um sucesso estrondoso, que transformou Gorki em artista com legiōes de admiradores. Mas o perfeccionista Stanislavski não ficou inteiramente satisfeito com seu próprio trabalho de ator. Para ele, como seu personagem era a tendência (política) personificada, ao fazê-lo acabou dando prioridade ao significado político-social da peça; isso produzia nele algum mal estar, pois não conseguia viver os pensamentos e sentimentos do personagem. Em sua avaliação, nunca chegou a alcançar esse objetivo.

Depois disso, os fundamentos do sistema stanislavskiano estavam lançados. E dispondo destas informaçōes talvez fique mais fácil acompanhar com serenidade e distanciamento (isto é: em atitude épica) a relação de Brecht com essa história.

\section{Identificação e distanciamento}

É compreensível que Stanislavski só tenha se tornado um assunto para Brecht quando este já se encontrava no exílio. Até a chegada de Hitler ao poder (1933), ele estava envolvido com a perspectiva de uma Revolução na Alemanha e com a sua própria revolução no teatro que, como se sabe, tinha entre seus opositores os veteranos do naturalismo alemão (inclusive críticos). Nunca é demais lembrar: estes também eram de esquerda e, de um modo geral, ligados ao Partido Socialista. E, pelo que ficou dito acima, também é compreensível que seu interesse em matéria de teatro soviético estivesse voltado para experiências como as do Agitprop e as de Meyerhold, mas devidamente preocupado com o modo como este último era recebido pela crí- tica alemã, como se pode ver num texto de 1930 sobre o assunto: em nome das "emoções", estes críticos descartavam a contribuição revolucionária do diretor para o teatro. Caprichando na ironia profunda, Brecht conta que eles reclamaram da falta de modos dos personagens ingleses na peça $A$ China brame, dirigida por Meyerhold e encenada em Berlim, acrescentando que reclamariam, numa eventual encenação de alguma peça sobre Átila, o huno, da omissão de seu amor pelas crianças (Cf. Brecht, 1989, p. 202).

Dentre as referências a Stanislavski datadas por Brecht, uma das mais recuadas é de 12 de setembro de 1938, em seu Diário de trabalho (1973). Ali Brecht registra que num jornal alemão editado em Moscou, o Deutsche ZentralZeitung, o Culto Stanislavski (cujo cadáver nem esfriou) vai de vento em popa. Polemizando com seus sacerdotes, aos quais chama de murxistas ${ }^{7}$, Brecht observa que no "método" a razão não é suprimida - longe disso, é um mecanismo de controle. Por exemplo, quando Stanislavski pede a um ator que a expressão seja justificada, ele quer ver a razão no palco. $\mathrm{O}$ argumento completo é mais pesado: aqueles sacerdotes que exaltam as emoçôes fingem não saber que elas são no mínimo tão corruptas quanto as funções racionais; eles desconsideram que todo pensamento necessário tem seu correlativo emocional e que todo sentimento tem o seu correlativo intelectual. O diagnóstico a respeito do processo em andamento é implacável: "a hipocrisia da Escola de Stanislavski, com seu templo da arte, sua celebração da palavra, seu culto do poeta, sua interioridade, sua pureza, sua exaltação, seu natural, do qual se teme sempre e inevitavelmente 'sair', nada mais é que o reflexo de seu atraso mental, de sua crença 'no' homem, 'nas' idéias, etc.” (Brecht, 1973, p. 26).

$\mathrm{O}$ maior interesse desta entrada do diário é a clara demonstração de que o problema de Brecht não é Stanislavski propriamente dito,

7 Trocadilho com a palavra alemã murksen, que significa trabalhar mal ou, melhor ainda, malbaratar. Cf. nota da edição citada, p. 561, que ainda lembra ser bastante freqüente este trocadilho em Brecht. 
mas a mistificação que teve início quando da adoção do realismo socialista como palavra de ordem stalinista para as artes em 1934, programa no qual, no âmbito da encenação teatral, coube a Stanislavski, malgré lui même, o papel de profeta, por assim dizer. Note-se, entretanto, que as 'sagradas escrituras' dessa religião só começaram a ser publicadas quando o culto já entrava em declínio até mesmo no âmbito oficial, não propriamente por acaso.

Como se sabe, Walter Benjamin refere-se a Brecht como dramaturgo dialético (Benjamin, 1992) ${ }^{8}$ e demonstra exaustivamente esta tese em seus ensaios sobre o companheiro de lutas. Provavelmente, o filósofo não teve acesso aos diários do amigo, quando ambos estiveram exilados (Ibid., p. 105-21) mas, se tivesse tido, haveria de dizer que a seguinte análise da identificação stanislavskiana é um bom exemplo de exercício de dialética, diretamente inspirado no Hegel da Ciência da Lógica:9 "de um lado, o ato de identificação recorre a elementos racionais e, de outro, o efeito de distanciamento pode ser aplicado de maneira puramente sentimental. Stanislavski desenvolveu longas análises para chegar à identificação, e o efeito de distanciamento dos panoramas de feira ('Nero contempla o incêndio de Roma' [...], 'o terremoto de Lisboa') é puro sentimento. No teatro aristotélico a identificação também é intelectual; o teatro nãoaristotélico também recorre à crítica sentimental." (Brecht, 1973, p. 142, 17/10/1940)

$\mathrm{Na}$ verdade - sempre no espírito brechtiano -, todo o mistério da identificação poderá ser dissolvido se recorrermos à providência dialética de historicizá-lo, o que Brecht naturalmente fez nos mais diversos momentos de seus Escritos sobre teatro e sobretudo no início de A compra do latão. O próprio trabalho de Stanislavski em busca da identificação entre ator e personagem - desenvolvido, como vimos acima, com as dificuldades para encenar peças de Ibsen, Tchekhov e Gorki, isto é, sob o signo do naturalismo - é, segundo Brecht, um avanço considerável na história das artes cênicas, no bojo de importantes conquistas sociais e culturais. Por isso observa: "o sistema de Stanislavski é um progresso pelo simples fato de ser um sistema. $\mathrm{O}$ jogo que ele desenvolve produz a identificação de maneira sistemática; esta, portanto, não é efeito do acaso, nem do humor, nem da inspiração. $\mathrm{O}$ conjunto [ensemble] alcança uma alta qualidade técnica que tem o objetivo de provocar uma identificação total do espectador. $O$ progresso em questão fica particularmente visivel depois que essa identificação começa a acontecer com personagens que até então não tinham nenhum papel no teatro: os proletários. Não é por acaso que na América foram justamente os teatros da esquerda que começaram a se apropriar do sistema de Stanislavski. Esse modo de representar tem a possibilidade de permitir uma identificação com o proletário, até então impossível.” (Brecht, 1989, p. 368, grifos nossos)

Ainda segundo Brecht, os esforços de Stanislavski para desenvolver um método para conseguir a identificação do ator com seu personagem mostram que desde fins do século XIX, justamente pelos novos problemas, situações e personagens que os melhores dramaturgos criaram, foi ficando cada vez mais difícil produzi-la. É neste ponto que os caminhos dos dois diretores se separam, pois enquanto Stanislavski trabalhou para salvar uma prática que tem a idade do drama (burguês), Brecht e outros (como Meyerhold) buscaram a sua superação. Aqui vale a pena passar a palavra a Brecht: "Muito ingenuamente, Stanislavski tratou as dificuldades como fraquezas passageiras, puramente negativas, que deviam e podiam ser superadas a

8 Especialmente o ensaio "The Country where it is forbidden to mention the proletariat" (p.37-41).

9 Fredric Jameson desenvolve este tópico em $O$ método Brecht, em especial no item 8 ("Da multiplicidade à contradição") da primeira parte (Doutrina). Cf. Jameson, F. 1999, p. 101-124. 
qualquer preço. [...] Não lhe ocorreu que as perturbações [no processo de identificação] pudessem ser conseqüência de mudanças irreversíveis que afetaram a consciência do homem moderno. [...] Se isto lhe ocorresse, talvez ele se tivesse perguntado se ainda era o caso de procurar promover a identificação total. Foi a questão que a teoria do teatro épico se colocou. $\mathrm{O}$ teatro épico se interessou pelas dificuldades, pelas perturbações - e se esforçou para encontrar um modo de atuar que permitisse renunciar à identificação total." (Ibid., p. 268-9) ${ }^{10}$

Voltando mais uma vez à determinação histórica do trabalho de Stanislavski, agora posto em perspectiva, em $A$ compra do latão, Brecht ao mesmo tempo faz o elogio e circunscreve o seu alcance: "As obras principais de Stanislavski, que aliás fazia muitas experiências e realizava peças fantásticas, foram as da época naturalista. No caso dele deve falar-se mesmo de obras pois, como é habitual com os russos, algumas de suas encenações já se realizam há mais de 30 anos sem qualquer modificação, embora sejam já interpretadas por atores diferentes. As suas obras naturalistas consistem então em retratos sociais minuciosamente executados. [...] A ação das peças é mínima, a ilustração pormenorizada dos estados de alma ocupa o tempo todo, trata-se de investigar a vida interior de algumas personagens individuais, no entanto há também alguma coisa para os investigadores sociais. Quando Stanislavski estava na força de sua idade, a revolução aconteceu. O seu teatro foi tratado com o máximo respeito. Vinte anos depois da revolução foi ainda possível estudar nesse teatro, como num museu, o modo de vida de camadas sociais entretanto desaparecidas." (Brecht, 1999, p. 18) ${ }^{11}$

\section{Aprender com Stanislavski}

Em 1947, quando ainda estava nos Estados Unidos, chegou às mãos de Brecht uma espécie de manual stanislavskiano publicado em Berlim com o título O livro alemão de Stanislavski, organizado por alemães veteranos das lutas teatrais dos anos 1920 que se refugiaram na URSS durante o nazismo. Observando que "aqui [nos EUA] também o stanislavskianismo significa um protesto contra o teatro mercantil”, não deixa de avisar que no tal manual "não se encontra um único exercício tirado da luta de classes", e que seus autores propõem um realismo curioso, "praticam um culto alambicado da realidade" (Brecht, 1973, p. 450, 15/09/1947) ${ }^{12}$. Algum tempo depois, a caminho de Berlim, volta a escrever sobre o manual: "o que particularmente me repugna [nele] é esse tom de moralismo tacanho" (Ibid., p. 464, 04/01/1948).

Todo mundo sabe que na Alemanha Oriental a ortodoxia soviética reinou quase absoluta, sobretudo nos primeiros anos da "reconstrução"; por isso não há necessidade de procurar detalhes sobre o modo como esse manual funcionou na vida teatral hegemônica no período (o Berliner Ensemble foi uma exceção mantida sob permanente vigilância). Para se armar o problema, é só lembrar que nem na URSS estavam

10 O problema das dificuldades é enfrentado nesta mesma chave por Adorno que, em ensaio com esse título publicado em Impromptus (1985), anuncia ter-se inspirado em "Cinco dificuldades para escrever a verdade", texto brechtiano de 1934 .

11 Como a tradução é portuguesa, pode ser oportuno esclarecer ao público brasileiro que as "peças fantásticas" a que se refere Brecht correspondem ao gênero que no Brasil se designa féerie; Stanislavski encenou nesse gênero $O$ pássaro azul de Maeterlinck, entre outras de muito sucesso.

12 A edição inglesa, anotada por John Willett, tem o cuidado de informar que o livro foi "compilado e publicado sob os auspícios soviéticos e era evidentemente destinado a ser a bíblia do realismo socialista, a nova ortodoxia na Alemanha Oriental". Cf. Brecht, 1993, p. 511. Para quem costuma se perguntar pelas horas, não é demais notar o atraso com que chegou essa "novidade" à Alemanha ocupada. 
disponíveis os textos do próprio Stanislavski. Daí o interesse que pode haver no conselho deste a Joshua $\operatorname{Logan}^{13}$, que o visitou em 1931 e deu notícia deste encontro na introdução ao livro $A$ construção da personagem: "Nosso método nos serve porque somos russos, porque somos este determinado grupo de russos aqui. Aprendemos por experiências, mudanças, tomando qualquer conceito gasto de realidade e substituindo-o por alguma coisa nova, algo cada vez mais próximo da verdade. Vocês devem fazer o mesmo. Mas ao seu modo e não ao nosso. O método que usamos em 1898 quando foi fundado o Teatro de Arte de Moscou já foi modificado mil vezes. Alunos meus, ou atores da nossa companhia se impacientaram e romperam conosco. Formaram novas companhias e hoje acham o Teatro de Arte de Moscou antiquado, fora de moda. Talvez eles descubram algo mais próximo da verdade do que nós descobrimos." (Logan, 1976, p. 7)

Se Brecht não conversou com o diretor sobre o assunto, provavelmente leu esta introdução, de 1949, na tradução americana do livro. Independente desta hipótese, é certo que Brecht conhecia essa disposição de Stanislavski para acolher e aprovar justamente os que procuraram novos rumos (novas e melhores verdades), ${ }^{14}$ o que também explica as suas insistentes manifestações favoráveis ao estudo das obras do diretor quando voltou à Alemanha.

Em 1951, o Comitê das Artes alemão começou a organizar, por assim dizer, uma Jornada de Estudos sobre Stanislavski que afinal acabou acontecendo em 17 a 19 de abril de 1953 (cf. nota da edição dos Ecrits sur le théâtre. Brecht, 1989, v. 2, p. 600). Como se pode depreender das observações de Brecht, as jornadas foram mal organizadas e pior realizadas, à base de muita improvisação e (acrescentaríamos) exercícios de dogmatismo explícito. Por isso Brecht escreveu que a organização precisava melhorar; a discussão devia ser também sobre teatro (!!!); as teses a serem debatidas nem sequer foram divulgadas; os participantes improvisaram tudo, e assim por diante (Ibid., p. 188). Suas propostas seguiam obviamente na direção contrária e contemplavam questôes elementares, como por exemplo: é preciso publicar os principais escritos de Stanislavski; é preciso historicizar Stanislavski, estudar cada fase de seu trabalho, saber o que ele mesmo apontou como errado ou insuficiente em seus próprios estudos, enfim, o que ele escreveu na última fase, a da construção do socialismo na URSS. Suas razões práticas: "Um breve estudo do modo de trabalho de Stanislavski basta para revelar uma grande riqueza de exercícios e de procedimentos úteis numa representação realista. Há muito o que aprender, mas é preciso realmente querer aprender" (Ibid., p. 189).

Por falar em querer aprender, Brecht recomenda a leitura de um livro publicado em 1952 na Alemanha, Stanislavski ensaiando, de Toporkov. Dá destaque ao trabalho com uma cena da peça Os dias dos Turbins, já referida aqui, em que ocorre a chegada do oficial ferido à casa da família. Toporkov conta que o elenco avançou rapidamente para a representação dos "transportes sentimentais" dos familiares e Stanislavski

13 Mais conhecido no Brasil como diretor de cinema (Picnic, 1956; Nunca fui santa, 1956; Camelot, 1967), tem origem no teatro musical. Os interessados em Brecht e Weill devem saber que foi o diretor do musical Knickerbocker Holiday (Maxwell Anderson e Kurt Weill, 1938), de onde vem a conhecida canção It never was you.

14 É impossível que ele não soubesse que Meyerhold só escapou da execução enquanto Stanislavski esteve vivo e pôde defendê-lo da sanha stalinista. Christine Edwards conta que a última aparição pública de Meyerhold aconteceu dez meses após a morte do mestre. Foi preso no dia seguinte à sua intervenção no Primeiro Congresso dos Diretores Teatrais da URSS, em que fez um discurso incendiário contra o realismo socialista. (Cf. Nicolai Gorchakov, apud Edwards, 1965, p. 97) 
criticou severamente o procedimento. Depois explicou aos atores o que eles estavam ignorando: naquela situação era prioritário providenciar um esconderijo para o ferido; aquelas pessoas estavam lidando com um oficial contra-revolucionário em plena guerra civil; não havia, portanto, tempo para se perder com "transportes sentimentais" (Ibid., p. 190). Deste episódio, Brecht abstraiu uma importante lição que os atores podem aprender com o teatro de Stanislavski - o sentimento de responsabilidade diante da sociedade: "Stanislavski ensinou aos atores a importância social do jogo teatral. Para ele, a arte não é um fim em si, mas ele sabia que no teatro nenhum objetivo é alcançado se não for pela arte" (Ibid., p. 191).

Por afinidades como estas, numa entrevista sobre as jornadas, Brecht afirmou que os teatros alemães podiam aprender muito com Stanislavski: "Posso citar de cabeça algumas coisas que é preciso estudar. O caráter diferenciado de suas representações, as inumeráveis sutilezas, a percepção dos aspectos contraditórios entre os seres e as situaçôes, o natural artístico, a luta incessante contra os doutrinários (que infestam os teatros). Há os esforços para estimular a imaginação dos atores e torná-la concreta. Há os exercícios para reforçar a observação e a percepção; indicações sobre a maneira pela qual o ator pode se livrar das influências perturbadoras da vida privada para ficar em condições de se consagrar inteiramente a seu papel; indicações sobre a maneira pela qual o ator pode realizar o ato de identificação com o personagem da obra." (Ibid., p. 193)

Para concluir, Brecht identifica particularmente duas afinidades entre seu próprio método e o do diretor russo. São elas a teoria das ações físicas e a compreensão do super-objetivo, tópicos a partir dos quais seria possível até falar em sistemas complementares, desde que se ultrapasse a mera contraposição entre identificação e distanciamento, percebendo o distanciamento como a superação dialética (a que preserva e contém em si o superado) da identificação. Sobre este ponto, é interessante a res- posta de Helene Weigel, quando perguntada sobre o uso da identificação: "Nós representamos para as pessoas, seres humanos que não são nós. Esse é o processo. Por que não haveríamos de ter consciência deste processo?” (Ibid., p. 187) Em outro lugar Brecht complementa: "Como dramaturgo, eu preciso da capacidade do ator de se identificar completamente e de se metamorfosear integralmente que Stanislavski foi o primeiro a pensar de modo sistemático; mas ao mesmo tempo, e acima de tudo, preciso da distância em relação ao personagem que o ator, enquanto representante da sociedade (de sua parte progressista), deve estabelecer" (Ibid., p. 197).

A partir desses apontamentos, talvez fique mais compreensível a manifestação crítica mais acabada sobre este problema, em $A$ compra do latão: "A última forma, até agora, de representar do teatro burguês assente numa base teórica elaborada, e que é associada ao grande dramaturgista e ator russo Stanislavski, utiliza uma técnica que pretende garantir a veracidade da representação. $\mathrm{O}$ comportamento dos atores não deve distinguir-se em nada, nem no mais pequeno pormenor, do comportamento dos homens na vida real. Através de um ato psíquico particular de identificação com a personagem a representar, o ator consegue imitações minuciosas das reações de pessoas reais. Este ato psíquico consiste numa introspecção profunda, na qual o ator entra por inteiro na alma da pessoa a representar, transformando-se a si próprio completamente nesta pessoa, um ato que, quando conseguido corretamente, é realizado também pelo espectador, de modo que também este se identifica completamente com a pessoa representada. Stanislavski, que tem o mérito de ter estudado este ato com rigor quase científico, e que especificou o que é preciso para o conseguir, não acha necessário defendê-lo contra qualquer tipo de crítica: não está de modo nenhum preparado para uma tal crítica. A identificação parece-lhe um fenômeno de todo inseparável da arte, tão inseparável que não se pode falar de arte quando ela não acontece. Alguém que queira contrariar esse conceito - e eu 
por exemplo vejo-me forçado a contrariá-lo encontra-se à partida numa situação difícil, pois não se pode negar que o fenômeno existe de fato na experiência artística pura e simples. [...] Nos últimos anos, alguns abandonaram todas as técnicas (e existem muitas, a de Stanislavski é só uma delas) que visam a obtenção da identificação completa. A razão para tal é que estas formas de representar permitem mostrar a verdade sobre a vida dos homens em comunidade (que é mostrada no teatro) só de uma maneira muito imperfeita.” (Brecht, 1999, p. 92-3)

\section{Leituras complementares}

O que Brecht apontou como possível complementaridade entre o seu sistema e o de Stanislavski, em relação ao trabalho do ator, aparece para quem trabalha com dramaturgia numa simples superposição das análises que ambos fizeram do Otelo de Shakespeare. Detalhe decisivo: Brecht tomou a de Stanislavski como ponto de partida.

A segunda parte de $A$ criação de um papel é dedicada ao Otelo. A forma dialogada da exposição responde pelo interesse em dar a conhecer os vários tipos de incompreensão, as leituras apressadas, para não falar nada das não-leituras de atores que se interessam apenas pelos próprios papéis sem se preocuparem nem mesmo com o significado geral da peça (o super-objetivo de Stanislavski). Como não teria propósito dar conta de cada episódio, ou incidente, passo a passo, vamos reproduzir aqui apenas os conselhos mais importantes do mestre, assim como as suas conclusões.

Para combater a idiotia do papel (comportamento do ator que não gosta de estudar nada, nem mesmo a própria peça em que vai atuar), Stanislavski dá este conselho: "vocês devem ler e ouvir tudo, todas as peças que puderem, críticas, comentários, opiniōes. Isso abastece e amplia o seu estoque de material criador. Mas ao mesmo tempo têm que aprender a salvaguardar sua independência e afastar os preconceitos. Vocês devem formar opiniōes próprias e não ir aceitando irrefletidamente as opiniōes alheias. Precisam aprender a ser livres. É uma arte difícil, que só dominarão por meio do conhecimento e da experiência. Estes, por sua vez, serão adquiridos não por meio de uma lei qualquer, mas por todo um complexo de conhecimentos teóricos e trabalho prático no campo da técnica artística, e principalmente pela reflexão pessoal, pela penetração nas essências, por muitos anos de prática." (Stanislavski, 1972, p. 117)

Ainda em função do mesmo interesse, acrescenta o mestre: "o estudo da literatura mundial os auxiliará tremendamente nesses processos. Em toda peça, como em todos os seres vivos, há uma estrutura óssea, membros: mãos, pés, cabeça, coração, cérebro. Uma pessoa literariamente treinada estudará, como o anatomista, a estrutura e a forma de cada osso e articulação, e reconhecerá os seus componentes. Dissecará a peça, avaliará o seu significado social, fará surgir seus erros, o ponto onde ela bloqueia o desenvolvimento do tema principal ou se desvia dele. Poderá perceber rumos novos e originais numa peça, suas características internas e externas, o entrelaçamento das falas, o inter-relacionamento dos personagens, os fatos, os acontecimentos. Toda esta ciência, habilidade e experiência é extraordinariamente importante na apreciação de uma obra.” (Ibid., p. 118)

Quanto ao Otelo, sem prejuízo da recomendação da leitura de todo o capítulo, para não falar de todo o livro (a análise do Inspetor Geral de Gogol é igualmente reveladora), limitemo-nos às principais conclusões. A certa altura, para explicar por que os atores têm que se interessar pela posição social dos personagens, diz Stanislavski: "Otelo rapta a filha de um alto dignitário, e o faz na posição de um estrangeiro, que por acaso está a serviço do Senado. Este é um conflito que envolve duas classes diferentes e também duas nacionalidades. Além disso, trata-se também da dependência do Senado em relação a um negro que eles desprezam. Para os venezianos, este conflito é toda a tragédia." (Ibid., p. 156) E, para ilustrar a necessidade de recorrer aos conhecimentos (pressupostos pelo 
texto) referidos acima, temos o seguinte comentário analítico: "Não haveria o amor entre Otelo e Desdêmona sem o êxtase romântico de uma linda jovem; sem as histórias fascinantes, lendárias do Mouro, sobre suas proezas militares; sem os inúmeros obstáculos ao seu casamento desigual, que despertam as emoções de uma visionária jovem revolucionária; sem a súbita guerra, que impõe o reconhecimento das núpcias de uma jovem aristocrática com o Mouro, para salvar o país. E não haveria ruptura entre as duas raças sem o esnobismo dos venezianos, sem a honra da aristocracia; sem o seu desdém pelos povos conquistados, a um dos quais o próprio Otelo pertence; sem uma sincera convicção do opróbrio que é misturar o sangue negro e o branco." (Ibid., p. 127)

Depois de ler esta análise, Brecht achou que só tinha a acrescentar o seguinte: com Stanislavski aprende-se "como deduzir da sociedade certas características de um personagem sobre as quais a ação se baseia. Exemplo: o ciúme de Otelo, que não é uma paixão 'eterna' e muito menos universal (veja-se o exemplo dos esquimós). Isto pode ser expresso no teatro.
Otelo não possui apenas Desdêmona, ele possui um cargo de general. Ele tem que defender seu cargo que the pode ser roubado. Shakespeare escolheu expressamente um general que não herdou seu cargo, mas o conquistou por feitos específicos, e sem dúvida roubou-o de alguém. É portanto um general assalariado; ele não é proprietário de sua posição de general - como seria o caso de um senhor feudal -, como conseqüência e expressão de sua situação na sociedade. Em suma, ele vive num mundo de complôs por propriedade e por posições, em que a posição é tratada como propriedade.

Da mesma forma, sua relação com a mulher amada se desenvolve como uma situação de propriedade. A paixão-ciúme, quando o teatro a mostra nestes termos, não fica diminuída; ao contrário, é aprofundada. Neste mesmo processo aparecem indicaçôes das possibilidades que a sociedade tem de intervir." (Brecht, 1989 , v. 2, p. 181) Este deveria ser, segundo Brecht, o objetivo de uma montagem épica do Otelo. E ele tem boas razões para acreditar que isto acaba correspondendo ao super-objetivo de Stanislavski.

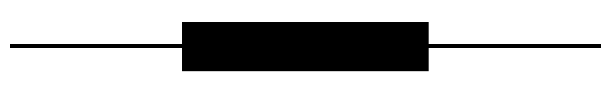

\section{Referências bibliográficas}

ADORNO, T. Impromptus. Barcelona: Laia, 1985.

BENJAMIN, W. Understanding Brecht. London: Verso, 1992.

BRECHT, B. Journal de Travail (1938-1955). Paris: L'Arche, 1973.

. Écrits sur le théâtre. Paris: L'Arche, 1989.

. Bertolt Brecht Journals (1934-1955). London: Routledge, 1993.

. A compra do latão. Lisboa: Vega, 1999.

EDWARDS, C. The Stanislavsky Heritage. New York: New York University Press, 1965.

JAMESON, F. O método Brecht. Petrópolis: Vozes, 1999. 
LOGAN, J. Introdução. In: STANISLAVSKI, C. A construção da personagem. Rio de Janeiro: Civilização Brasileira, 1976.

RUDNITSKY, K. Russian and Soviet Theatre. London: Thames \& Hudson, 2000.

STANISLAVSKI, C. A criação de um papel. Rio de Janeiro: Civilização Brasileira, 1972. Mi vida en el arte. La Habana: Arte y Literatura, 1985.

TCHEKHOV, A.P. Cartas a Suvórin (1886-1891). São Paulo: Edusp, 2002. 